\title{
ANALISIS NILAI KAPASITAS STRUKTUR ATAS JEMBATAN DENGAN MENGGUNAKAN METODE RATING FACTOR
}

\author{
Andika Arief Saputra ${ }^{1}$, Hrc. Priyosulistyo ${ }^{2}$, Muslikh $^{3}$ \\ 1, 2, 3 Departemen Teknik Sipil dan Lingkungan FT UGM \\ Email: andika.saputra18@gmail.com
}

\begin{abstract}
ABSTRAK
Jembatan merupakan infrastruktur transportasi yang vital. Jika suatu jembatan mengalami kegagalan maka lumpuhlah sistem tersebut. Oleh karena itu, kajian ini bertujuan untuk mengetahui nilai kapasitas sisa jembatan eksisting sehingga dapat dinilai bahwa jembatan tersebut masih layak digunakan atau tidak. Kajian ini dilakukan pada segmen P1-P5 (arah Dawuan) jembatan Cinapel yang terletak di Kabupaten Sumedang. Jembatan ini merupakan jembatan beton prategang. Metode kajian yang digunakan adalah metode load rating factor. Dilakukan dengan menghitung kapasitas dukung gelagar dan plat lantai kendaraan. Standar perhitungan dengan mengacu pada Peraturan Penentuan Bridge Load Rating untuk Jembatan Eksisting dari Menteri Pekerjaan Umum dan Perumahan Rakyat (03/SE/M/2016). Dari hasil perhitungan didapatkan hasil bahwa nilai $R F$ gelagar bentang tepi, bentang tengah, dan plat lantai kendaraan memiliki nilai $>1$ yang artinya bahwa struktur jembatan Cinapel bentang P1-P5 arah Dawuan aman dalam melayani lalu lintas yang melintasi jembatan.
\end{abstract}

Kata kunci: jembatan beton prategang, load rating factor, struktur atas

\begin{abstract}
Bridges are vital transportation infrastructure. If a bridge fails then the system is chaos. Therefore, this study aims to determine the remaining capacity of the existing bridge where the bridge is still suitable for use or not. This research was conducted on the P1-P5 segment (Dawuan direction) Cinapel bridge located in Sumedang Regency. This bridge is a prestressed concrete bridge. The research method used is the load rating factor method. It was carried out by calculating the carrying capacity of the girder and slab of the bridge. Calculation refer to the Determination for Existing Bridges using Load Rating Factor of the Minister of Public Works and Public Housing (03/SE/M/2016). The results of calculation obtained that the RF of the outer span girder, middle span, and slab are greater than 1 ( $R F>1)$ which means that the structure of the Cinapel bridge span P1-P5 is safe.
\end{abstract}

Keywords: prestressed concrete bridge, load rating factor, upper structure

\section{PENDAHULUAN}

Jembatan adalah bangunan pelengkap jalan yang berfungsi sebagai penghubung dua ujung jalan yang terputus oleh sungai, saluran, lembah, dan selat atau laut, jalan raya, dan jalan kereta api (Direktorat Jenderal Bina Marga, 2003) Sehingga akses transportasi satu daerah dengan daerah lainnya akan lebih mudah. Jika suatu jembatan runtuh atau tidak berfungsi dengan baik (mengalami kegagalan fungsi) maka akan mengganggu fungsi sistem transportasi secara keseluruhan.

Kegagalan fungsi jembatan akibat kegagalan jembatan dalam melayani beban lalu lintas yang melewatinya dapat dihindari dengan melakukan evaluasi komponen jembatan terhadap pembebananpembebanan tertentu secara berkala. Pada ajian ini evaluasi jembatan menggunakan metode Rating Factor untuk menghitung kapasitas dukung dengan mengacu pada peraturan Pedoman Penentuan Bridge Load Rating untuk Jembatan Eksisting dari Menteri Pekerjaan Umum (03/SE/M/2016). Sedangkan analisis tampang jembatan mengacu pada Perencanaan Struktur Beton untuk Jembatan (RSNI T-12-2004).

Kajian ini mengambil studi kasus Jembatan Cinapel yang terletak pada ruas jalan tol Cisumdawu di Kabupaten Sumedang, Jawa Barat. Beton prategang adalah beton yang mengalami tegangan dalam (internal) yang 
besar dan distribusi tegangan sedemikian rupa sehingga dapat mengimbangi tegangan yang terjadi akibat beban luar (eksternal) sampai dengan batas tertentu. Tegangan internal tersebut dapat mengurangi pengaruh tegangan tarik beton akibat beban eksternal sehingga dapat mengurangi retak-retak rambut yang terjadi pada beton. Dengan kata lain, gaya pratekan akan memberikan tegangan awal yang berlawanan dengan gaya tarik yang ditimbulkan oleh beban eksternal sehingga tegangan tarik total akan berkurang atau hilang sama sekali (Triwiyono, 2010). Konsep ini dapat dijelaskan dengan Gambar 1 berikut ini.

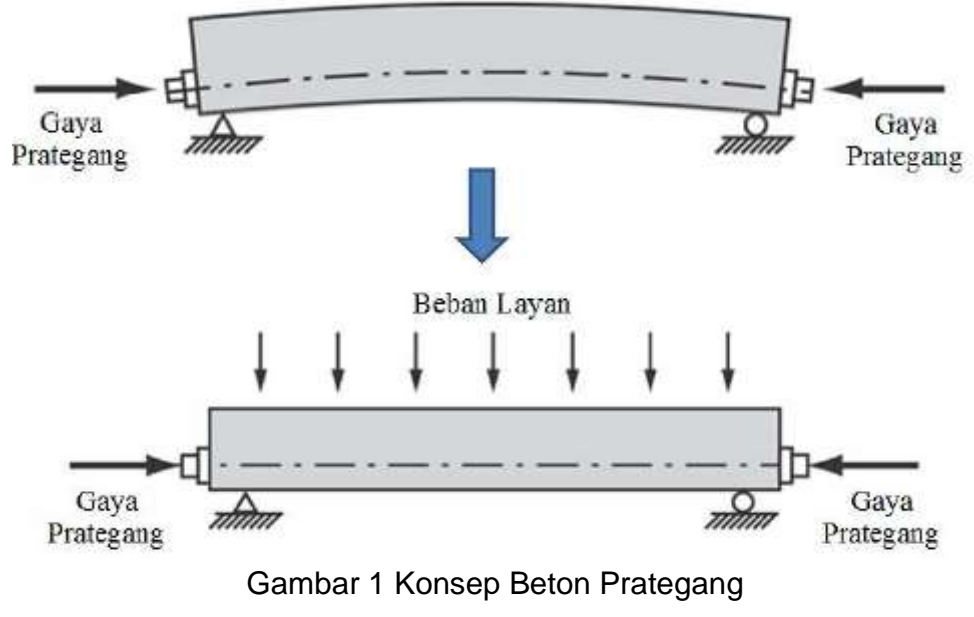

\section{METODE}

Metode evaluasi jembatan yang digunakan dalam analisis ini adalah perhitungan load rating yang akan menghasilkan output nilai rating factor $(R F)$. $R F$ merupakan perbandingan antara nilai sisa kapasitas tampang jembatan setelah melayani beban mati dengan beban lalu lintas. Di Indonesia mengacu pada peraturan Pedoman Penentuan Bridge Load Rating untuk Jembatan Eksisting dari Menteri Pekerjaan Umum (03/SE/M/2016). Pedoman ini memuat dua prosedur dalam perhitungan load rating antara lain penilaian beban desain dan penilaian beban khusus. 


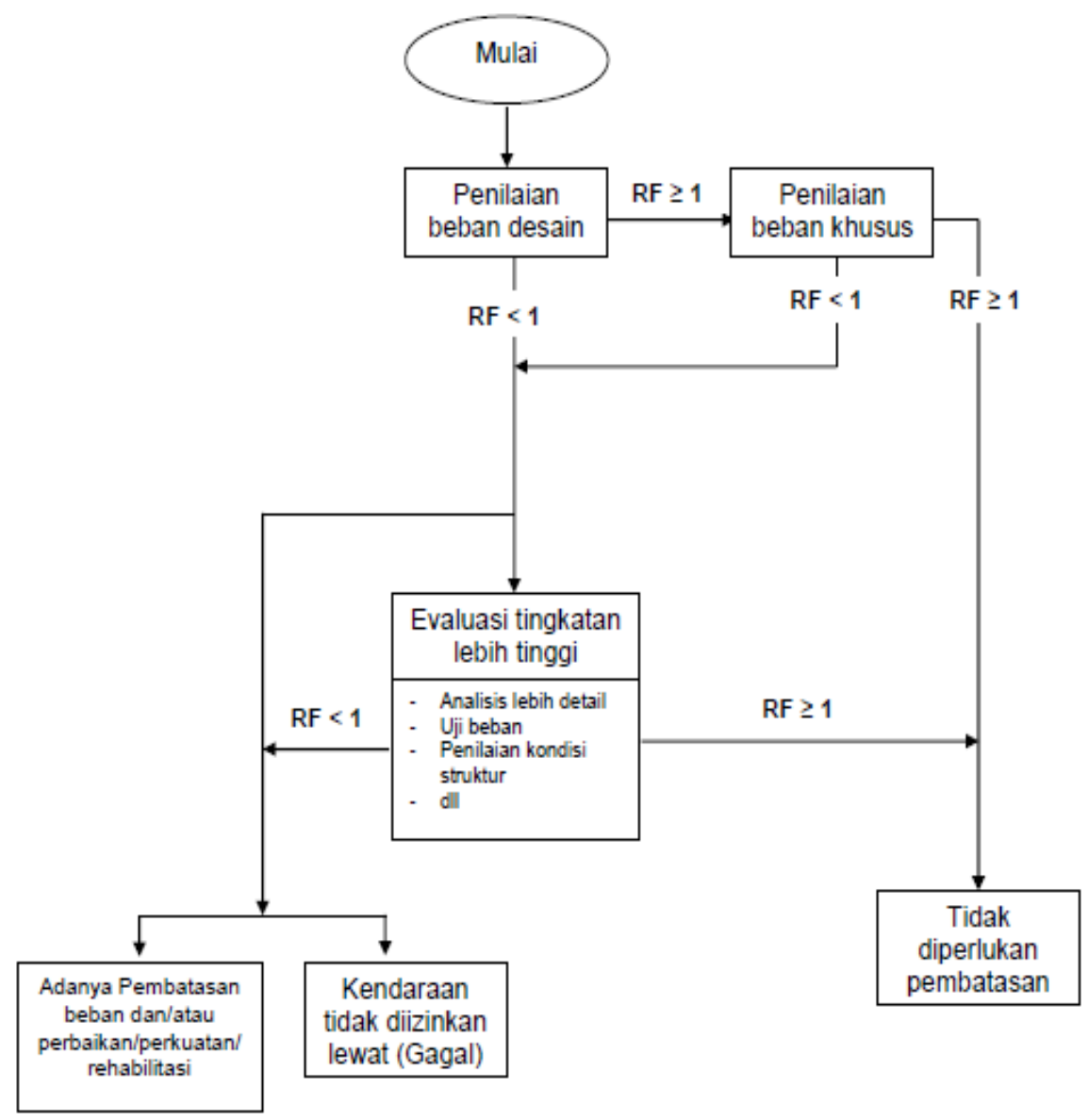

Gambar 2 Tahapan untuk penilaian beban (SE Menteri PUPR, 2016)

Dalam analisis juga harus diperhitungkan kehilangan tegangan yang terjadi, yaitu:

a. Kehilangan tegangan akibat dudukan angker, $\mathrm{A}$ dapat dihitung dengan:

$$
\Delta f_{p A}=\frac{\Delta_{A}}{L} E_{p}
$$

dengan $\Delta_{A}$ adalah besar gelincir tendon, dan $L$ adalah panjang tendon.

b. Kehilangan tegangan akibat perpendekan elastis beton, ES dapat dihitung dengan

$$
\Delta f_{p E S}=\frac{1}{n} \sum_{j=1}^{n}\left(\Delta f_{p E S}\right)_{j} \ldots \ldots \ldots \ldots
$$

dengan $n$ adalah banyaknya tendon yang ditarik secara sekuensial, $\left(\Delta f_{p E S}\right)_{j}$ adalah kehilangan tegangan maksimal.

c. Kehilangan tegangan akibat rangkak, CR dapat dihitung dengan

$$
\Delta f_{p C R}=K_{C R} \frac{E_{S}}{E_{\text {balok }}}\left(f_{C S}-f_{c s d}\right) \ldots
$$

dengan $K_{C R}: \quad 2,0$ untuk komponen struktur pratarik, 1,6 untuk komponen struktur pasca tarik.

d. Kehilangan tegangan akibat susut, SH dapat dihitung dengan persamaan yang diambil dari Prestressed Concrete Institute

$$
\Delta f_{\text {pGH }}=8,2 \cdot 10^{-6} K_{s H} E,\left(1-0,06 \frac{V}{S}\right)(100-R H)
$$

dengan $K_{S H}$ adalah koefisien yang dipengaruhi oleh jeda waktu antara akhir perawatan beton sampai pemberian tegangan, $E_{p}$ adalah modulus elastisitas baja tendon, $R H$ adalah skala kelembaban relatif untuk wilayah Indonesia adalah $70 \%$. 
e. Kehilangan tegangan akibat relaksasi baja tendon, $\mathrm{R}$ dihitung dengan

$\Delta f_{p R}=\left[K_{R E}-J *\left(\Delta P_{E S}+\Delta P_{C R}+\Delta P_{S H}\right)\right] C$

dengan nilai $K_{R E}$ dan $J$ dapat diperoleh pada Tabel 2 dan nilai $C$ pada Tabel 3. f. Kehilangan tegangan akibat friksi/gesekan, $\mathrm{F}$ dapat dihitung dengan persamaan berikut: $\Delta f_{p F}=f_{i}(\mu \alpha+K L)$

dengan nilai koefisien kelengkungan $(\mu)$ dan koefisien wobble $(K)$ dapat diperoleh pada Tabel 4.

Tabel 1. Nilai $K_{S H}$ untuk komponen struktur pasca tarik (E.G. Nawy, 2001)

\begin{tabular}{|c|c|c|c|c|c|c|c|c|}
\hline $\begin{array}{l}\text { Jeda waktu antara perawatan basah beton } \\
\text { sampai pemberian tegangan (hari) }\end{array}$ & 1 & 3 & 5 & 7 & 10 & 20 & 30 & 60 \\
\hline$K_{S H}$ & 0,92 & 0,85 & 0,8 & 0,77 & 0,73 & 0,61 & 0,58 & 0,45 \\
\hline \multicolumn{9}{|c|}{ Tabel 2. Nilai $K_{R E}$ dan J (T.Y. Lin, 1998) } \\
\hline \multicolumn{3}{|l|}{ Tipe tendon } & \multicolumn{3}{|c|}{$K_{R E}(\mathrm{MPa})$} & \multicolumn{3}{|c|}{$J$} \\
\hline \multicolumn{3}{|l|}{ Strand atau kawat stress relieved derajat $1860 \mathrm{MPa}$} & \multicolumn{3}{|c|}{138} & \multicolumn{3}{|c|}{0,15} \\
\hline \multicolumn{3}{|l|}{ Strand atau kawat stress relieved derajat $1720 \mathrm{MPa}$} & \multicolumn{3}{|c|}{128} & \multicolumn{3}{|c|}{0,14} \\
\hline \multicolumn{3}{|c|}{ Kawat stress relieved derajat $1655 \mathrm{MPa}$ atau $1620 \mathrm{MPa}$} & \multicolumn{3}{|c|}{121} & \multicolumn{3}{|c|}{0,13} \\
\hline \multicolumn{3}{|c|}{ Strand relaksasi rendah derajat $1860 \mathrm{MPa}$} & \multicolumn{3}{|c|}{35} & \multicolumn{3}{|c|}{0,040} \\
\hline \multicolumn{3}{|l|}{ Strand relaksasi rendah derajat $1720 \mathrm{MPa}$} & \multicolumn{3}{|c|}{32} & \multicolumn{3}{|c|}{0,037} \\
\hline \multicolumn{3}{|c|}{ Strand relaksasi rendah derajat $1655 \mathrm{MPa}$ atau $1620 \mathrm{MPa}$} & \multicolumn{3}{|c|}{30} & \multicolumn{3}{|c|}{0,035} \\
\hline \multicolumn{3}{|c|}{ Batang stress relieved derajat $1000 \mathrm{MPa}$ atauu $1100 \mathrm{MPa}$} & \multicolumn{3}{|c|}{41} & \multicolumn{3}{|c|}{0,05} \\
\hline
\end{tabular}

Tabel 3. Nilai $C$ (E.G Nawy, 2001)

\begin{tabular}{|c|c|c|}
\hline $\boldsymbol{f}_{p i} / \boldsymbol{f}_{p u}$ & $\begin{array}{l}\text { Strand atau kawat } \\
\text { stress relieved }\end{array}$ & $\begin{array}{c}\text { Batang stress relieved atau strand } \\
\text { atau kawat relaksasi rendah }\end{array}$ \\
\hline 0,80 & - & 1,28 \\
\hline 0,79 & - & 1,22 \\
\hline 0,78 & - & 1,16 \\
\hline 0,77 & - & 1,11 \\
\hline 0,76 & - & 1,05 \\
\hline 0,75 & 1,45 & 1,00 \\
\hline 0,74 & 1,36 & 0,95 \\
\hline 0,73 & 1,27 & 0,90 \\
\hline 0,72 & 1,18 & 0,85 \\
\hline 0,71 & 1,09 & 0,80 \\
\hline 0,70 & 1,00 & 0,75 \\
\hline 0,69 & 0,94 & 0,70 \\
\hline 0,68 & 0,89 & 0,66 \\
\hline 0,67 & 0,83 & 0,61 \\
\hline 0,66 & 0,78 & 0,57 \\
\hline 0,65 & 0,73 & 0,53 \\
\hline 0,64 & 0,68 & 0,49 \\
\hline 0,63 & 0,63 & 0,45 \\
\hline 0,62 & 0,58 & 0,41 \\
\hline 0,61 & 0,53 & 0,37 \\
\hline 0,60 & 0,49 & 0,33 \\
\hline
\end{tabular}

Tabel 4 Nilai $\mu$ dan $k$ (E.G Nawy, 2001)

\begin{tabular}{lcc}
\hline \multicolumn{1}{c}{ Jenis tendon } & Koefisien wobble $(\boldsymbol{K})$ & Koefisien kelengkungan $(\boldsymbol{\mu})$ \\
\hline Tendon diselubungi metal fleksibel & $0,0010-0,0015$ & \\
Tendon kawat & $0,0005-0,0020$ & $0,15-0,25$ \\
Strand 7 kawat & $0,0001-0,0006$ & $0,08-0,25$ \\
Batang mutu tinggi & 0,0002 & $0,15-0,25$ \\
\hline Tendon di saluran metal yang rigid & & \\
Strand 7 kawat & & \\
\hline Tendon yang dilapisi mastic &
\end{tabular}




\begin{tabular}{lcc}
\hline \multicolumn{1}{c}{ Jenis tendon } & Koefisien wobble $(\boldsymbol{K})$ & Koefisien kelengkungan $(\boldsymbol{\mu})$ \\
\hline Tendon kawat dan strand 7 kawat & $0,0010-0,0020$ & $0,05-0,15$ \\
\hline Tendon yang dilumasi dahulu & & \\
Tendon kawat dan strand 7 kawat & $0,0003-0,0020$ & $0,05-0,15$ \\
\hline
\end{tabular}

Perhitungan kapasitas tampang elemen jembatan dengan mengacu pada peraturan RSNI T-12-2004. Kapasitas tampang adalah menghitung besar kekuatan nominal tampang $\left(R_{n}\right)$ pada struktur terhadap momen lentur maupun gaya geser.

a. Kapasitas momen lentur plat

Pada plat dengan tebal efektif $d$, maka besar momen lentur nominal yang dapat ditahan oleh tampang plat adalah

$$
\begin{aligned}
& A_{s}=\frac{1}{4 s} \pi D^{2} b \ldots \ldots \ldots \ldots \ldots \ldots \ldots \ldots \ldots \ldots \\
& M_{n}=0,85 f_{c}^{\prime} a b\left(d-\frac{1}{2} a\right) \ldots \ldots \ldots \ldots
\end{aligned}
$$

dengan $s$ adalah jarak tulangan, a adalah kedalaman blok tekan, $b$ adalah lebar plat, dan $d$ adalah tinggi efektif tulangan tarik.

b. Kapasitas geser plat

Untuk kapasitas geser plat tanpa tulangan geser arah panjang dan lebar sesuai peraturan RSNI T-02-2004 sebagai berikut

$$
V_{n}=\frac{1}{6} \sqrt{f_{c}^{\prime}} d b
$$

c. Kapasitas momen lentur balok
Kekuatan batas nominal penampang beton prategang terhadap lentur $\left(M_{n}\right)$ dihitung berdasarkan cara kekuatan batas, dengan asumsi-asumsi yang sama dengan perhitungan beton bertulang, yaitu dengan mengganti besaran tegangan leleh $\left(f_{y}\right)$ menjadi tegangan analitis batas baja prategang $\left(f_{p s}\right)$.

Penampang beton bertulang mencapai keadaan seimbang jika regangan beton pada serat tepi tertekan sebesar, $\varepsilon_{c}=0,003$ dan regangan baja tarik tepat mencapai luluh. Ketentuan mengenai distribusi tegangan tekan berbentuk segi empat dianggap terpenuhi dengan asumsi tegangan tekan merata sebesar $0,85 f_{c}^{\prime}$ 'bekerja pada luas bidang yang dibatasi oleh:

a. Tepi dari penampang

b. Garis sejajar sumbu netral pada kondisi batas akibat beban yang diperhitungkan, yang terletak pada jarak $a=\beta_{1} c$ dari serat tekan terluar, dimana $\beta_{1}$ ditetapkan sebagai berikut:

- $\quad \beta_{1}=0,85$ untuk $f_{c}{ }^{\prime} \leq 30 \mathrm{MPa}$

- $\quad \beta_{1}=0,85-0,008\left(f_{c}{ }^{\prime}-30\right)$ dengan $\beta_{1}>0,65$ untuk $f_{c}{ }^{\prime} \geq 30 \mathrm{MPa}$

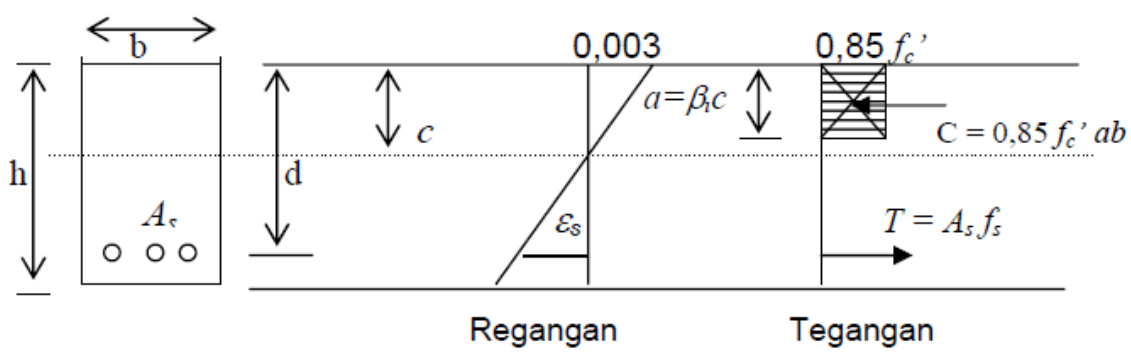

Gambar 3 Blok regangan dan tegangan tekan beton (RSNI T-12-2004)

Tegangan analitis batas baja prategang,

$f_{p s}$ ditentukan dengan persamaan berikut:

$f_{p s}=f_{p u}\left(1-\frac{\gamma_{p}}{\beta_{1}}\left[\rho_{p} \frac{f_{p u}}{f_{c}^{\prime}}+\frac{d}{d_{p}}\left(\omega-\omega^{\prime}\right)\right]\right)$

Momen nominal, 


$$
M_{n}=A_{i} 0,85 f_{c}^{\prime} y_{i}
$$

dengan $A_{i}$ adalah luas beton efektif, $y_{i}$ adalah jarak titik berat tendon terhadap pusat plat, $d=0 \mathrm{~mm}$ karena tulangan non prategang diabaikan, $\rho_{p}$ adalah rasio luas penampang baja tendon terhadap luas beton.

d. Kapasitas geser balok

Persamaan untuk menghitung kuat geser nominal yang mampu ditahan balok jembatan adalah

$$
V_{n}=V_{c}+V_{s}
$$

Kuat geser nominal oleh beton dihitung dengan persamaan

$$
V_{c i}=\frac{\sqrt{f_{c}^{\prime}}}{20} b_{w} d+V_{d}+\frac{V_{i} M_{c r}}{M_{\max }} \ldots .
$$

Dengan $b_{w}$ adalah lebar badan balok, $V_{d}$ adalah gaya geser akibat beban mati, $V_{i}$ adalah gaya geser akibat beban luar, $M_{c r}$ adalah momen retak yang terjadi

Kuat geser nominal oleh tulangan geser dihitung dengan persamaan

$$
V_{S}=\frac{A_{v} f_{y} d_{p}}{s} \ldots \ldots \ldots \ldots \ldots \ldots \ldots
$$

dengan $A_{v}$ adalah luas tulangan geser, $d_{p}$ adalah jarak serat tekan terluar ke titik berat tulangan prategang, $s$ adalah jarak tulangan.

Persamaan umum untuk menentukan nilai load rating (rating factor) pada setiap komponen struktur jembatan yang terkait dengan salah satu gaya dalam tertentu menurut 03/SE/M/2016 adalah
$R F=\frac{C-\left(\gamma_{D C}\right)(D C)-\left(\gamma_{D W}\right)(D W) \pm\left(\gamma_{F}\right)(P)}{\left(\gamma_{L L}\right)(L L+I M)}$

dengan $C$ adalah kapasitas tampang jembatan, $D C$ adalah pengaruh beban mati akibat komponen struktur dan pelengkap, $D W$ adalah pengaruh beban mati akibat komponen tambahan, $L L$ adalah pengaruh beban hidup.

Untuk kondisi batas kekuatan (strength limit states) dengan persamaan berikut.

$$
C=\varphi_{c} \varphi_{s} \varphi R_{n}
$$

Kondisi batas

a. Faktor beban

Faktor beban untuk jembatan dengan struktur beton bertulang ditunjukkan pada Tabel 5

b. Faktor kondisi adalah faktor reduksi kapasitas tampang struktur akibat adanya kerusakan pada struktur atau kerusakan yang diperkirakan terjadi pada struktur yang ditinjau. Nilainya ditunjukkan dalam Tabel 6.

c. Faktor sistem

Merupakan faktor pengali pada tahanan nominal struktur yang merepresentasikan tingkat redundansi sistem struktur jembatan. Nilai dari faktor sistem ditunjukkan dalam Tabel 7.

Tabel 5. Faktor beban (SE Menteri PUPR, 2016)

\begin{tabular}{lcc}
\hline \multicolumn{1}{c}{ Beban } & Notasi Faktor Beban & Nilai \\
\hline $\begin{array}{l}\text { Beban mati dari komponen struktural dan } \\
\text { pelengkap jembatan }\end{array}$ & $\gamma_{D C}$ & 1,25 \\
\hline $\begin{array}{l}\text { Beban mati dari lapisan permukaan dan } \\
\text { utilitas jembatan }\end{array}$ & $\gamma_{D W}$ & 1,50 \\
\hline Beban hidup & $\gamma_{L L}$ & $\begin{array}{l}\text { Beban desain (inventory) }=1,80 \\
\text { Beban khusus (operatory) }=1,50\end{array}$ \\
\hline
\end{tabular}


Analisis Nilai ... (Andika/ hal 1-12)

Tabel 6. Faktor kondisi, $\varphi_{c}$ (SE Menteri PUPR, 2016)

\begin{tabular}{clcc}
\hline $\begin{array}{c}\text { Nilai kondisi } \\
\text { bangunan atas }\end{array}$ & \multicolumn{1}{c}{ Deskripsi kondisi } & \multicolumn{2}{c}{$\varphi_{c}$} \\
\cline { 3 - 4 } & \multicolumn{1}{c}{$\begin{array}{c}\text { Jembatan dalam keadaan baru tanpa kerusakan cukup jelas. } \\
\text { Elemen jembatan berada dalam kondisi baik. }\end{array}$} & 1,00 & 1,00 \\
\hline 0 & $\begin{array}{l}\text { Kerusakan sangat sedikit (dapat diperbaiki dengan } \\
\text { pemeliharaan rutin tidak berdampak pada keamanan atau } \\
\text { fungsi jembatan }\end{array}$ & 1,00 & 1,00 \\
\hline 1 & $\begin{array}{l}\text { Kerusakan yang memerlukan pemantauan atau } \\
\text { pemeliharaan di masa yang akan datang, memberikan } \\
\text { tanda-tanda diperlukan penggantian }\end{array}$ & 0,90 & 1,00 \\
\hline 3 & $\begin{array}{l}\text { Kerusakan yang membutuhkan perhatian (kemungkinan } \\
\text { akan menjadi serius dalam 1 bulan) }\end{array}$ & 0,70 & 0,70 \\
\hline 4 & $\begin{array}{l}\text { Kondisi kritis, kerusakan yang membutuhkan tindakan } \\
\text { segera }\end{array}$ & 0,30 & 0,30 \\
\hline 5 & Runtuh atau tidak berfungsi lagi & 0 & 0 \\
\hline
\end{tabular}

Tabel 7 Faktor sistem, $\varphi_{\varepsilon}$ (SE Menteri PUPR, 2016)

\begin{tabular}{lc}
\hline \multicolumn{1}{c}{ Elemen } & $\varphi_{s}$ \\
\hline Lentur & 0,80 \\
\hline Geser dan torsi & 0,70 \\
\hline Aksial tekan dengan tulangan spiral & 0,70 \\
\hline Aksial tekan dengan sengkang biasa & 0,65 \\
\hline Tumpuan beton & 0,70 \\
\hline
\end{tabular}

HASIL DAN PEMBAHASAN

\section{Analisis penampang balok}

a. Section properties balok prategang

Luas total balok prategang, $A=$ $0,78236 \mathrm{~m}^{2}$

Letak titik berat dari bawah, $y_{b}=1,0092 \mathrm{~m}$

Letak titik berat dari atas, $y_{a}=1,908 \mathrm{~m}$

Momen inersia terhadap titik berat,

$$
I_{x}=0,416 \mathrm{~m}^{4}
$$

b. Section properties balok komposit

Tinggi total balok komposit, $h_{c}=2,35 \mathrm{~m}$

Luas total balok komposit, $A_{c}=1,1288 \mathrm{~m}^{2}$

Letak titik berat dari bawah, $y_{b c}=1,382 \mathrm{~m}$

Letak titik berat dari atas, $y_{a c}=0,967 \mathrm{~m}$

Momen inersia terhadap titik berat, $I_{x c}=$ $0,773 \mathrm{~m}^{4}$

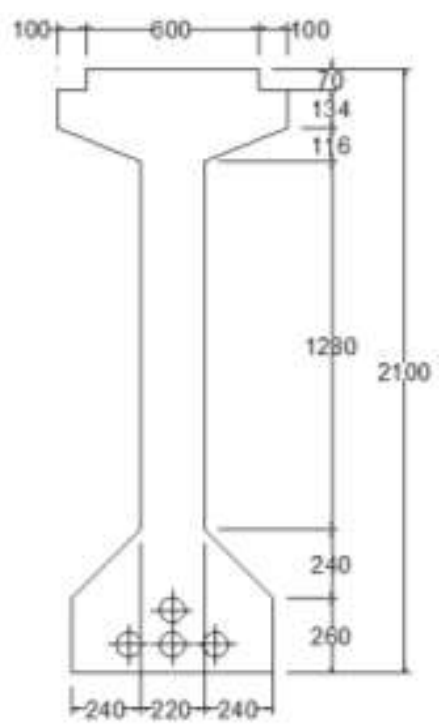

Gambar 4 Dimensi girder 


\section{Pembebanan balok}

a. Beban sendiri (DC)

Balok prategang

Berat balok, $\mathrm{W}_{\text {balok }}=809,9 \mathrm{kN}$

Beban balok, $Q_{\text {balok }}=19,95 \mathrm{kN} / \mathrm{m}$

Plat lantai

Beban plat, $Q_{\text {plat }}=12,5 \mathrm{kN} / \mathrm{m}$

Parepet

Beban parepet, $Q_{\text {parepet }}=8,525 \mathrm{kN} / \mathrm{m}$

b. Beban permukaan (DW)

Aspal+overlay

Beban aspal, $Q_{\text {aspal }}=1,1 \mathrm{kN} / \mathrm{m}$

Genangan

Beban genangan, $Q_{\text {genangan }}=0,5 \mathrm{kN} / \mathrm{m}$ c. Beban lajur (TD)

Beban merata, $Q_{\text {TD }}=15,65 \mathrm{kN} / \mathrm{m}$

Beban terpusat $P_{T D}=137,2 \mathrm{kN}$

d. Gaya rem (TB)

Gaya rem, $\mathrm{T}_{\mathrm{TB}}=63,28 \mathrm{kN}$

Lengan beban dari titik tangkap gaya ke titik berat gelagar, $y=2,82 \mathrm{~m}$

e. Beban lalu lintas (TB)

Beban hidup kendaraan yang diaplikasikan pada model struktur jembatan adalah sebagai berikut:

a. Beban standar AASHTO (design truck, design tandem, dan design lane);

b. Beban standar SNI

$B_{\text {eff }}$
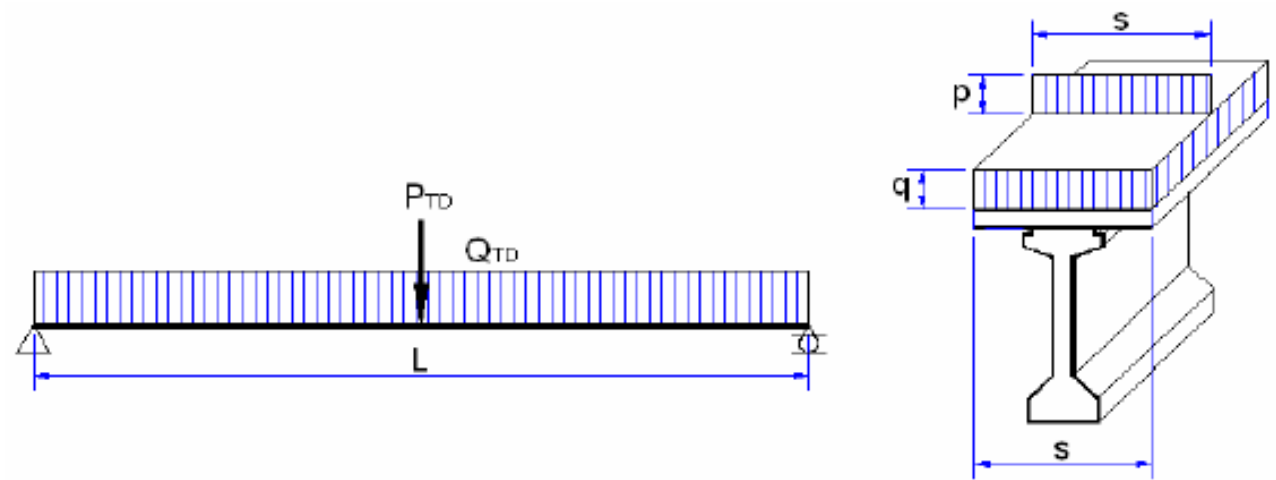

Gambar 5. Beban lajur

Hasil perhitungan pembebanan yang diaplikasikan pada model SAP2000 ditunjukkan pada tabel di bawah ini.

Tabel 8. Hitungan SAP pada struktur frame akibat beban kendaraan standar AASHTO

\begin{tabular}{ccc}
\hline $\begin{array}{c}\text { Load } \\
\text { Case }\end{array}$ & $\begin{array}{c}\text { Momen Lentur } \\
(\mathbf{k N m})\end{array}$ & $\begin{array}{c}\text { Gaya Geser } \\
\mathbf{( k N )}\end{array}$ \\
\hline DC & $8.571,202$ & 185,911 \\
\hline DW & 666,927 & 14,163 \\
\hline AP 1 & 910,7678 & 117,855 \\
\hline AP 2 & 649,5077 & 107,563 \\
\hline AP 3 & 538,6347 & 107,088 \\
\hline AP 4 & 495,114 & 107,036 \\
\hline AP 5 & 495,114 & 107,036 \\
\hline AP 6 & 538,6347 & 107,088 \\
\hline AP 7 & 649,5077 & 107,563 \\
\hline
\end{tabular}

\begin{tabular}{l}
\hline AP $8 \quad 910,7678$ \\
Momen lentur maksimal $=910,76 \mathrm{kNm}$ \\
Gaya geser maksimal $=117,85 \mathrm{kN}$.
\end{tabular}

Tabel 9. Hitungan SAP pada struktur plat akibat beban kendaraan standar AASHTO

\begin{tabular}{ccc}
\hline $\begin{array}{c}\text { Load } \\
\text { Case }\end{array}$ & $\begin{array}{c}\text { Momen Lentur } \\
(\mathbf{k N m})\end{array}$ & $\begin{array}{c}\text { Gaya Geser } \\
\mathbf{( k N )}\end{array}$ \\
\hline DC & 113,7629 & 145,56 \\
\hline DW & 8,7246 & 13,07 \\
\hline AP 1 & 16,0088 & 18,39 \\
\hline AP 2 & 8,0148 & 4,83 \\
\hline AP 3 & 7,0581 & 4,67 \\
\hline AP 4 & 6,9898 & 4,63 \\
\hline AP 5 & 6,9898 & 6,1 \\
\hline AP 6 & 7,0581 & 6,1 \\
\hline
\end{tabular}


Analisis Nilai ... (Andika/ hal 1-12)

\begin{tabular}{ccc}
\hline AP 7 & 8,0148 & 8,45 \\
\hline AP 8 & 16,0088 & 18,39
\end{tabular}

Momen lentur maksimal $=16,00 \mathrm{kNm}$

Gaya geser maksimal $=18,39 \mathrm{kN}$

\section{Gaya prategang}

a. Kondisi awal (saat transfer)

Diambil gaya prategang awal dari lapangan, $P_{t}=10.302,385 \mathrm{kN}$ untuk bentang tepi, dan $P_{t}=9.730,03 \mathrm{kN}$ untuk bentang tengah.

Tabel 10. Hitungan SAP pada struktur frame akibat beban kendaraan standar SNI

\begin{tabular}{ccc}
\hline Load Case & $\begin{array}{c}\text { Momen Lentur } \\
\text { (kNm) }\end{array}$ & $\begin{array}{c}\text { Gaya Geser } \\
\text { (kN) }\end{array}$ \\
\hline DC & $8.571,202$ & 185,911 \\
\hline DW & 666,927 & 14,163 \\
\hline Kombinasi 1 & $2.082,379$ & 36,368 \\
\hline Kombinasi 2 & $1.064,363$ & 26,565 \\
\hline Kombinasi 3 & $1.969,571$ & 81,331 \\
\hline Kombinasi 4 & $2.262,378$ & 98,249 \\
\hline Kombinasi 5 & $1.762,069$ & 155,129 \\
\hline
\end{tabular}

Momen lentur maksimal $=2.262,37 \mathrm{kNm}$

Gaya geser maksimal $=155,12 \mathrm{kN}$

Tabel 11 Hitungan SAP pada struktur plat akibat beban kendaraan standar SNI

\begin{tabular}{ccc}
\hline Load Case & $\begin{array}{c}\text { Momen Lentur } \\
(\mathbf{k N m})\end{array}$ & $\begin{array}{c}\text { Gaya Geser } \\
\mathbf{( k N )}\end{array}$ \\
\hline DC & 113,7629 & 145,56 \\
\hline DW & 8,7246 & 13,07 \\
\hline Kombinasi 1 & 20,2456 & 16,76 \\
\hline Kombinasi 2 & 13,407 & 10,99 \\
\hline Kombinasi 3 & 15,6587 & 13,34 \\
\hline Kombinasi 4 & 25,9722 & 20,65 \\
\hline Kombinasi 5 & 23,6623 & 18,3 \\
\hline
\end{tabular}

Momen lentur maksimal $=25,97 \mathrm{kNm}$

Gaya geser maksimal $=20,65 \mathrm{kN}$

b. Keadaan akhir

Prosentase tegangan leleh yang timbul pada baja (\% jacking force), $P_{o}=89,86$ $\%$.

Gaya prategang akibat jacking $\left(P_{j}\right)=$ $12.120,45 \mathrm{kN}$ untuk bentang tepi, dan $11.447,09 \mathrm{kN}$ untuk bentang tengah.

Kehilangan gaya prategang (loss of prestress/LoP) ditunjukkan pada tabel 12.

Tabel 12 Besar LoP pada setiap obyek

\begin{tabular}{lccc}
\hline \multicolumn{1}{c}{ Loss of prestress } & & \multicolumn{2}{c}{$\%$} \\
\cline { 2 - 4 } & & Bentang tepi & Bentang tengah \\
\hline LoP akibat angkur & $A$ & 1,81 & 1,81 \\
\hline $\begin{array}{l}\text { LoP akibat perpendekan elastis } \\
\text { beton }\end{array}$ & $E S$ & 6,73 & 6,28 \\
\hline LoP akibat rangkak & $C R$ & 20,85 & 19,41 \\
\hline LoP akibat susut & $S H$ & 1,94 & 1,94 \\
\hline LoP akibat relaksasi baja & $R$ & 0,52 & 0,58 \\
\hline LoP akibat gesekan & $F$ & 6,44 & 6,44 \\
\hline \multicolumn{1}{c}{ Total } & & 38,32 & 36,49 \\
\hline
\end{tabular}

\section{Perhitungan kapasitas nominal}

a. Kapasitas momen nominal plat

$$
\begin{aligned}
& M_{n}=0,85 f_{c}^{\prime} a b\left(d-\frac{1}{2} a\right) \\
& M_{n}=330,829 \mathrm{kNm}
\end{aligned}
$$

b. Kapasitas geser nominal plat

$$
\begin{aligned}
& V_{c}=\frac{1}{6} \sqrt{f_{c}^{\prime}} b d \\
& V_{n}=V_{c}=387,057 \mathrm{kN}
\end{aligned}
$$

c. Kapasitas momen nominal balok

$$
M_{n}=0,85\left(B_{\text {eff }} \text { a) } f_{c}^{\prime} y\right.
$$

$M_{n}=26.860 \mathrm{kNm}$ untuk bentang tepi, dan $25.842 \mathrm{kNm}$ untuk bentang tengah

d. Kapasitas geser nominal balok Kuat geser oleh beton

$$
V_{c i}=\frac{\sqrt{f_{c}^{\prime}}}{20} b_{w} d+V_{d}+\frac{V_{i} M_{c r}}{M_{\max }}
$$


$V_{c i}=209,93 \mathrm{kN}$ untuk bentang tepi, dan $210,22 \mathrm{kN}$ untuk bentang tengah

Kuat geser oleh tulangan geser

$V_{s}=\frac{A_{v} f_{y} d_{p}}{s}$

$V_{s}=2.113,95 \mathrm{kN}$

Sehingga $V_{n}=2.323,88 \mathrm{kN}$ untuk bentang tepi dan $V_{n}=2.324,7 \mathrm{kN}$ untuk bentang tengah.

\section{Nilai rating factor}

Faktor beban

$\gamma_{D C}=1,25 ; \gamma_{D W}=1,50 ; \gamma_{L L i}=1,75$ untuk inventory, dan $\gamma_{L L o}=1,35$ untuk operatory Kapasitas tampang komponen jembatan $(C)$ Faktor kondisi, $\varphi_{c}=1,00$ (kondisi baik) Faktor sistem, $\varphi_{s}=0,80$ untuk lentur dan 0,7 untuk geser

Faktor tahanan LRFD, $\varphi=1,0$

Hasil hitungan $R F$ ditunjukkan pada tabel $13,14,15,16,17$, dan 18.

Tabel 13. Hitungan RF pada bentang tepi akibat beban kendaraan standar AASHTO

\begin{tabular}{|c|c|c|c|c|c|c|}
\hline \multirow{2}{*}{$\begin{array}{l}\text { Respon } \\
\text { struktur }\end{array}$} & \multirow{2}{*}{$\begin{array}{c}\text { Kapasitas } \\
\text { tahanan }\end{array}$} & \multirow{2}{*}{\multicolumn{3}{|c|}{ Besar respon struktur }} & \multicolumn{2}{|c|}{ Rating factor } \\
\hline & & & & & Inventory & Operating \\
\hline \multirow{2}{*}{ Momen lentur } & $M_{n}(\mathrm{kNm})$ & $M_{D C}(\mathrm{kNm})$ & $M_{D W}(\mathrm{kNm})$ & $M_{L L \_I M}(\mathrm{kNm})$ & \multirow{2}{*}{5,962} & \multirow{2}{*}{7,154} \\
\hline & $26.859,66$ & $8.571,20$ & 666,93 & 910,76 & & \\
\hline \multirow{2}{*}{ Gaya geser } & $V_{n}(\mathrm{kN})$ & $V_{D C}(\mathrm{kNm})$ & $V_{D W}(\mathrm{kNm})$ & $V_{L L \_I M}(\mathrm{kNm})$ & \multirow{2}{*}{6,473} & \multirow{2}{*}{7,767} \\
\hline & $2.323,88$ & 185,91 & 14,163 & 117,85 & & \\
\hline
\end{tabular}

Tabel 14. Hitungan RF pada bentang tengah akibat beban kendaraan standar AASHTO

\begin{tabular}{|c|c|c|c|c|c|c|}
\hline \multirow{2}{*}{$\begin{array}{l}\text { Respon } \\
\text { struktur }\end{array}$} & \multirow{2}{*}{$\begin{array}{c}\text { Kapasitas } \\
\text { tahanan }\end{array}$} & \multirow{2}{*}{\multicolumn{3}{|c|}{ Besar respon struktur }} & \multicolumn{2}{|c|}{ Rating factor } \\
\hline & & & & & Inventory & Operating \\
\hline \multirow{2}{*}{ Momen lentur } & $M_{n}(\mathrm{kNm})$ & $M D C(\mathrm{kNm})$ & $M D w(\mathrm{kNm})$ & $M L L_{-} I M(\mathrm{kNm})$ & \multirow{2}{*}{5,465} & \multirow{2}{*}{6,558} \\
\hline & $25.841,51$ & $8.571,20$ & 666,93 & 910,76 & & \\
\hline \multirow{2}{*}{ Gaya geser } & $V_{n}(\mathrm{kN})$ & $V_{D C}(\mathrm{kNm})$ & $V_{D W}(\mathrm{kNm})$ & $V_{L L I M}(\mathrm{kNm})$ & \multirow{2}{*}{6,474} & \multirow{2}{*}{7,768} \\
\hline & $2.324,16$ & 185,91 & 14,163 & 117,85 & & \\
\hline & bel 15. Hitu & RF pada & kibat beb & araar & ASHTO & \\
\hline \multirow{2}{*}{$\begin{array}{l}\text { Respon } \\
\text { struktur }\end{array}$} & \multirow{2}{*}{$\begin{array}{c}\text { Kapasitas } \\
\text { tahanan }\end{array}$} & \multirow{2}{*}{\multicolumn{3}{|c|}{ Besar respon struktur }} & \multicolumn{2}{|c|}{ Rating factor } \\
\hline & & & & & Inventory & Operating \\
\hline \multirow{2}{*}{ Momen lentur } & $M_{n}(\mathrm{kNm})$ & $M_{D C}(\mathrm{kNm})$ & $M_{D W}(\mathrm{kNm})$ & $M_{L L \_I M}(\mathrm{kNm})$ & \multirow{2}{*}{3,796} & \multirow{2}{*}{4,555} \\
\hline & 330,83 & 113,762 & 8,725 & 16,008 & & \\
\hline \multirow{2}{*}{ Gaya geser } & $V_{n}(\mathrm{kN})$ & $V_{D C}(\mathrm{kNm})$ & $V_{D W}(\mathrm{kNm})$ & $V_{L L \_I M}(\mathrm{kNm})$ & \multirow{2}{*}{2,096} & \multirow{2}{*}{2,515} \\
\hline & 387,06 & 145,56 & 13,07 & 18,39 & & \\
\hline
\end{tabular}

Tabel 16. Hitungan RF pada bentang tepi akibat beban kendaraan standar SNI

\begin{tabular}{|c|c|c|c|c|c|c|}
\hline \multirow{2}{*}{$\begin{array}{l}\text { Respon } \\
\text { struktur }\end{array}$} & \multirow{2}{*}{$\begin{array}{c}\text { Kapasitas } \\
\text { tahanan }\end{array}$} & \multirow{2}{*}{\multicolumn{3}{|c|}{ Besar respon struktur }} & \multicolumn{2}{|c|}{ Rating factor } \\
\hline & & & & & Inventory & Operating \\
\hline \multirow{2}{*}{ Momen lentur } & $M_{n}(\mathrm{kNm})$ & $M_{D C}(\mathrm{kNm})$ & $M_{D W}(\mathrm{kNm})$ & $M_{L L \_I M}(\mathrm{kNm})$ & \multirow[b]{2}{*}{2,400} & \multirow{2}{*}{2,880} \\
\hline & $26.859,66$ & $8.571,20$ & 666,93 & $2.262,38$ & & \\
\hline \multirow{2}{*}{ Gaya geser } & $V_{n}(\mathrm{kN})$ & $V_{D C}(\mathrm{kNm})$ & $V_{D W}(\mathrm{kNm})$ & $V_{L L \_I M}(\mathrm{kNm})$ & \multirow{2}{*}{4,917} & \multirow{2}{*}{5,901} \\
\hline & $2.323,88$ & 185,91 & 14,163 & 155,13 & & \\
\hline
\end{tabular}

Tabel 17. Hitungan RF pada bentang tengah akibat beban kendaraan standar SNI

\begin{tabular}{|c|c|c|c|c|c|c|}
\hline \multirow{2}{*}{$\begin{array}{l}\text { Respon } \\
\text { struktur }\end{array}$} & \multirow{2}{*}{$\begin{array}{c}\text { Kapasitas } \\
\text { tahanan }\end{array}$} & \multirow{2}{*}{\multicolumn{3}{|c|}{ Besar respon struktur }} & \multicolumn{2}{|c|}{ Rating factor } \\
\hline & & & & & Inventory & Operating \\
\hline Momen lentur & $\begin{array}{r}M_{n}(\mathrm{kNm}) \\
2584151\end{array}$ & $\frac{M_{D C}(\mathrm{kNm})}{8.571 .20}$ & $\frac{M_{D W}(\mathrm{kNm})}{666.93}$ & $\frac{M L L_{-} M}{226238}$ & 2,200 & 2,640 \\
\hline Gaya geser & $\frac{V_{n}(\mathrm{kN})}{2.324,16}$ & $\frac{V_{D C}(\mathrm{kNm})}{185,91}$ & $\frac{V_{D W}(\mathrm{kNm})}{14,163}$ & $\frac{V_{L L I M}(\mathrm{kNm})}{155,13}$ & 4,918 & 5,902 \\
\hline
\end{tabular}

Tabel 18. Hitungan RF pada plat akibat beban kendaraan standar SNI

\begin{tabular}{|c|c|c|c|c|c|c|}
\hline \multirow{2}{*}{$\begin{array}{l}\text { Respon } \\
\text { struktur }\end{array}$} & \multirow{2}{*}{$\begin{array}{c}\text { Kapasitas } \\
\text { tahanan }\end{array}$} & \multirow{2}{*}{\multicolumn{3}{|c|}{ Besar respon struktur }} & \multicolumn{2}{|c|}{ Rating factor } \\
\hline & & & & & Inventory & Operating \\
\hline Momen lentur & $M_{n}(\mathrm{kNm})$ & $M_{D C}(\mathrm{kNm})$ & $M_{D W}(\mathrm{kNm})$ & $M L L \_I M(\mathrm{kNm})$ & 2,340 & 2,807 \\
\hline
\end{tabular}


Analisis Nilai ... (Andika/ hal 1-12)

\begin{tabular}{ccccccc}
\hline \multirow{2}{*}{ Gaya geser } & $V_{n}(\mathrm{kN})$ & $V_{D C}(\mathrm{kNm})$ & $V_{D W}(\mathrm{kNm})$ & $V_{L L I M}(\mathrm{kNm})$ & \multirow{2}{*}{1,867} & \multirow{2}{*}{2,240} \\
\cline { 2 - 5 } & 387,06 & 145,56 & 13,07 & 20,65 & & \\
\hline
\end{tabular}

\section{SIMPULAN}

Balok gelagar bentang tepi jembatan Cinapel segmen P1-P5 jalur arah Dawuan memiliki kapasitas $M_{n}=26.859,663 \mathrm{kNm}$ dan $V_{n}=2.321,532 \mathrm{kN}$ yang lebih besar daripada momen lentur dan gaya geser yang terjadi akibat pembebanan yaitu sebesar 8.571,20 kNm dan 185,91 kN; Balok gelagar bentang tengah jembatan Cinapel segmen P1-P5 jalur arah Dawuan memiliki kapasitas $M_{n}=25.841,73 \mathrm{kNm}$ dan $V_{n}=2.321,924 \mathrm{kN}$ yang lebih besar daripada momen lentur dan gaya geser yang terjadi akibat pembebanan yaitu sebesar $8.571,20 \mathrm{kNm}$ dan 185,91 kN; Plat lantai jembatan Cinapel segmen P1-P5 jalur arah Dawuan memiliki kapasitas sebagai berikut: $M_{n}=330,829 \mathrm{kNm}$ dan $V_{n}=387,057$ $\mathrm{kN}$ yang lebih besar daripada momen lentur dan gaya geser yang terjadi akibat pembebanan yaitu sebesar $330,829 \mathrm{kNm}$ dan $387,057 \mathrm{kN}$; Nilai $R F$ yang dihitung dengan menggunakan beban kendaraan standar AASHTO lebih besar nilainya dibandingkan jika dihitung menggunakan beban kendaraan standar SNI, hal ini karena beban kendaraan standar AASHTO lebih kecil dibandingkan dengan beban kendaraan standar SNI; Berdasarkan hitungan $R F$ pada elemen gelagar dan plat yang ditinjau, diperoleh nilai $R F$ untuk momen lentur adalah bervariasi dari 1,92 s/d 6,65. Sedangkan $R F$ untuk gaya geser adalah bervariasi dari 2,48 s/d 8,63. Artinya adalah struktur jembatan Cinapel bentang P1-P5 arah Dawuan layak dan mampu dalam melayani lalu lintas yang melewati jembatan.

\section{DAFTAR RUJUKAN}

AASHTO, 2012. AASHTO LRFD Bridge Design Specification. 6th ed. Washington, DC: American Association of State Highway and Transportation Officials.
Aldo, A., \& Pratama, G. N. I. (2019). EVALUASI KETAHANAN GEMPA RUMAH SEDERHANA DI KELURAHAN RUM, KOTA TIDORE KEPULAUAN. INformasi dan Ekspose hasil Riset Teknik Slpil dan Arsitektur, 15(2), 1-9.

Andreas Triwiyono, 2010, Bahan Kuliah Struktur Beton Prategang, Jurusan Teknik Sipil FT UGM, Yogyakarta.

Badan Standardisasi Nasional, RSNI T-122004: Perencanaan Struktur Beton untuk Jembatan, ICS BSN.

Badan Standardisasi Nasional, SNI 031729-2002: Tata Cara Perencanaan Struktur Baja untuk Bangunan Gedung, ICS BSN.

Badan Standardisasi Nasional, SNI 1725:2016: Pembebanan untuk Jembatan, ICS BSN.

Dion Alkilla Asmaraman, 2017, Analisis Ulang Struktur Atas Jembatan Gelagar I Beton Prategang berdasarkan Standar Peraturan Terbaru (Studi Kasus Jembatan Srandakan 2, Kulon Progo, D.I. Yogyakarta), Departemen Teknik Sipil dan Lingkungan Fakultas Teknik Universitas Gadjah Mada, Yogyakarta.

Henricus Priyosulistyo, 2011, Struktur Beton Bertulang I, Biro Penerbit KMTS FT UGM , Yogyakarta.

Iman Satyarno, Analisis Struktur Jembatan, Jurusan Teknik Sipil FT UGM, Yogyakarta. 
Kementerian Pekerjaan Umum dan Perumahan Rakyat, 2016, Pedoman Penentuan Bridge Load Rating untuk Jembatan Eksisting, Pusat Litbang Jalan dan Jembatan, Bandung.

Muhammad Fauzi Darmawan, 2017, Evaluasi Kelayakan Struktur Atas Jembatan Tipe Concrete Slab dengan Metode Load Rating Factor mengacu The AASHTO's Manual for Bridge Evaluation (MBE) $2^{\text {nd }}$ Edition 2013 (Studi kasus: Jembatan Kali Pepe Segmen 3, Ruas Jalan Bebas Hambatan Solo-Kertosono, Jalur Arah Sragen), Departemen Teknik Sipil dan Lingkungan Fakultas Teknik Universitas Gadjah Mada, Yogyakarta.

Nawy, E. G., 2001, Beton Prategang Suatu Pendekatan Mendasar Jilid 1, Erlangga, Jakarta.

Roosseno, 1950, Pemberian Bentuk dan Penggunaan Material yang Minimum dalam Beton Bertulang, Pidato Pengukuhan Guru Besar Universitas Indonesia. Jakarta. 